\title{
PENINGKATAN PEMAHAMAN DALAM PEMBUATAN WEB SEDERHANA BAGI SISWA SISWI DI SMKN 1 BUMIJAWA
}

\author{
Dairoh $^{1 *}$, M. Yoka1, Ginanjar Wiro Sasmito ${ }^{1}$, Mc.Chambali ${ }^{2}$, Djatmiko Indrianto ${ }^{3}$, \\ Atmo Gayuh Laksmono $S^{3}$
}

\author{
${ }^{1}$ Program Studi DIV Teknik Informatika, Politeknik Harapan Bersama, Tegal, Indonesia \\ ${ }^{2}$ Program Studi DIII Teknik Elektro, Politeknik Negeri Semarang, Semarang, Indonesia \\ ${ }^{3}$ Program Studi DIII Teknik Komputer, Politeknik Harapan Bersama, Tegal, Indonesia \\ *Penulis Korespodensi: zaroh31@yahoo.co.id
}

\begin{abstract}
Abstrak
Sekolah Menengah Kejuruan (SMK) Negeri 1 Bumijawa yang merupakan salah satu sekolah menengah kejuruan di kabupaten Tegal yang terletak dikaki gunung Slamet dengan jarak \pm 50 dari kampus politeknik Harapan Bersama. Di Sekolah tersebut sistem jaringan komputer sudah sangat memadai, hal ini dibuktikan tersedia nya labortorium yang memadai. Selain itu disekolah tersebut terdapat berbagai jurusan, salah satunya adalah jurusan teknik komputer jaringan. Guna meningkatkan pengetahuan softskill dan hardskill siswa pada dunia industri nantinya, salah satunya adalah pengetahuan dalam pemanafaatan Teknologi Informasi dan Komunikasi (TIK) khususnya pada pemahaman pembuatan web sederhana. Maka dilakukan kegiatan pengabdian masyarakat di Sekolah Menengah Kejuruan (SMK) tersebut dengan memberikan teori pengetahuan dan praktek pendampingan secara langsung kepada siswa-siswa selama 3 hari yakni dalam pembuatan web. Peningkatan pemahaman dalam pembuatan web tersebut dimaksudkan guna meningkatkan keterampilan hard skill kepada peserta. Kegiatan tersebut dimaksudkan untuk dapat menambah pengalaman pengetahuan tentang web sederhana dan memotivasi siswa untuk mengetahui lebih dalam tentang pembuatan web khususnya web sederhana. Hasilnya menunjukkan bahwa peserta sangat antusias mengikuti, peserta dapat mengenal, membuat, menggunakan serta mengelola web dinamis berupa blog dan peserta pelatihan telah memiliki web dinamis berupa blog.
\end{abstract}

Kata kunci: Sekolah Menengah Kejuruan Negeri 1 Bumijawa, Web sederhana, Blog.

\begin{abstract}
Vocational High School (SMK) 1 Bumijawa which is one of the vocational high schools in Tegal regency located at the foot of Mount Slamet with a distance of \pm 50 from the Harapan Bersama polytechnic campus. At the school the computer network system was very adequate, this proved to be an adequate laboratory. In addition there are various departments in the school, one of which is a computer network engineering department. Vocational education is part of the education system that prepares graduates to have enough stock to be able to work in companies and master the experience of one field of work from many other occupations. In order to increase students' soft skills and hard skills knowledge in the industrial world later, one of them is knowledge in the use of Information and Communication Technology (ICT), especially in the understanding of making simple web. For this reason, understanding on the simple web can later be applied in the world of work or after graduating from vocational school. Then carried out community service activities at the Vocational High School (SMK) by providing knowledge theory and practice of mentoring directly to students for 3 days namely in making the web. Increased understanding in making the web is intended to improve the hard skills of the participants. The activity is intended to be able to add to the experience of knowledge about the simple web and motivate students to find out more about making web specifically the simple web. The results showed that the participants were very enthusiastic to follow, participants could recognize, create, use and manage dynamic web in the form of blogs and the trainees already had a dynamic web in the form of blogs.
\end{abstract}

Keywords: Vocational High School, Simple Web, Blog.

\section{PENDAHULUAN}

Seiring perkembangan teknologi saat ini, kita dituntut untuk bias bersaing dan berkompetensi untuk menguasai ilmu pengetahuan teknologi informasi. Dimana teknologi informasi adalah faktor pendukung yang sangat efektif pada masa sekarang dan mendatang 
yang memungkinkan masyarakat untuk menggunakan dan menikmati kemudahan dari teknologi informasi. Dimana website dapat memberi informasi menjadi sangat efisien dan terbaru (up to date). Sehingga website dapat diakses dan dimanfaatkan oleh kalangan masyarakat siapapun, dimana dan kapanpun (Hasugian, 2018). Salah satunya pemanfaatan website yang digunakan siswa sekolah guna untuk peningkatan skill.

Menurut Pendapat Arief (2011:7) didalam jurnal Wibisono \& Susanto, 2015 bahwa web merupakan salah satu aplikasi yang terisikan dokument-dokument multimedia dimana didalamnya memuat gambar, suara, teks, animasi, video dll). Selain Itu, fungsi web yaitu media pembelajaran, media promosi, media informasi media pendidikan dan media komunikasi (Wibisono \& Susanto, 2015).

Website merupakan kumpulan dari halaman-halaman situs yang terangkum pada domain atau subdomain yang berada didalam word wide web (WWW) didalam internet. Website adalah sebuah media informasi yang ada di internet. Selain itu website tidak saja dapat digunakan dalam penyebaran informasi saja melainkan bisa digunakan untuk membuat toko online. Didalam sebuah halaman web yaitu dokument yang ditulis pada format HTML (Hyper Text Markup Language) yang bias bias diakses melalui HTTP (Trimarsiah \& Arafat, 2017).

Web sederhana (web dinamis) merupakan sebuah web yang isinya dpat dirubah sewkatu waktu tanpa melalui perubahan code pada file web, akan tetapi perubahan tersebut melalui aksi dari user / pengunjung maupun administrator. Pada web dinamis dimungkin terjadi interaksi antar pengunjung dengan pemilik web, interaksi pengunjung dengan pengunjung misalnya memberikan komentar, upload file (Kadir, 2002).

Menurut Arif \& Barnawi, 2012:13 bahwa Sekolah Menengah Kejuruan (SMK) Adalah salah satu lembaga pendidikan yang bertanggungjawab menghasilkan Sumber daya manusia dengan dibekali kemampuan, keterampilan dan keahlian, hal ini diaharapkan lulusannya siswa SMK mengembangkan kinerja pada saat terjun dalam dunia kerja (Edi dkk, 2017).

Pendidikan kejuruan merupakan bagian dari sistem pendidikan yang mempersiapkan lulusannya memiliki bekal yang cukup guna bekerja di perusahaan serta menguasai satu bidang pekerjaan dari sekin banyak bidang pekerjaan lainnya. Karena saat masih menimba ilmu di SMK, lulusannya mendalami setiap bidang studi atau pendidikan kejuruan yang mengarah siap pakai ketika memasuki dunia kerja.

Menurut data Dinas Pendidikan dan Kebudayaan Kabupaten Tegal bahwa Sekolah Menengah Kejuruan (SMK) Negeri 1 Bumi Jawa merupakan salah satu Sekolah Menengah Kejuruan Negeri yang ada di Kabupaten Tegal. Berdasarkan data profil di Sekolah Menengah Kejuruan Negeri 1 Bumijawa bahwa kompetensi keahlian yang ada Di SMK tersebut antara lain jurusan Teknik Komputer jaringan (TKJ), Teknik Kendaraan Ringan (TKR), Teknik dan Bisnis Sepeda Motor (TBSM), Teknik Instalasi Pemanfaatan Tenaga Listrik (TITL), Teknik Otomatisasi Industri (TOI) dan multimedia (http://www.smkn1bmj.sch.id/). Salah satu Kompetensi keahlian yang ada di SMK tersebut adalah teknik komputer jaringan. Dimana Di SMK tersebut sistem ICT yang memadai hal ini ini dibuktikan dengan terdapatnya laboratorium komputer dan sistem jaringan internet yang memadai. Selain itu, persaingan dunia kerja saat ini sangat ketat, baik secara softskill maupun hardskill. Perkembangan teknologi yang sangat pesat mendorong dunia pendidikan khusunya siswa SMK untuk dapat menyiapkan para alumni yang siap masuk dalam dunia kerja dan dapat bersaing secara nasional dan global. Sehingga siswa SMK perlu dibekali pengetahuan guna menambah skill berupa pemahaman dalam pembuatan web khususnya pengetahuan pada web sederhana agar dapat menambah dan meningkatkan keterampilan hardskill pada siswa SMK N 1 Bumijawa. Sehingga peningkatan pemahaman pada web sederhana tersebut harapannya dapat menambah pengalaman skill, memotivasi siswa untuk mengetahui lebih dalam tentang pembuatan web khususnya web sederhana dan membekali siswa-siswi SMK Negeri 1 Bumijawa nanti nya dalam menerapkan dalam dunia kerja.

Berdasarkan analisis situasi tersebut, maka dapat diambil beberapa perumusan masalah, diantaranya : a. Bagaimana siswa dapat membuat web sederhana yang dapat di manfaatkan sebagai bekal setelah lulus dari SMK dan sebagai penunjang hardskill bagi siswa nantinya. b. Bagaimana memberikan sebuah solusi dalam pemahaman jaringan. Kegiatan pengabdian ini bertujuan memberikan teori dan pelatihan kepada siswa SMK 1 Bumijawa untuk memanfaatkan teknologi jaringan dalam membuat web sederhana.

\section{BAHAN DAN METODE}

Metode kegiatan yang dilakukan pada kegiatan pengabdian ini adalah dengan metode presentasi, diskusi, praktek pelatihan dan pendampingan. Secara keseluruhan metode pelaksanaan kegiatan pengabdian masyarakat ini sebagai berikut:

a. Tahap Persiapan

Tahap persiapan meliputi melakukan kunjungan awal mitra, hal ini di maksudkan untuk mengetahui kondisi mitra, selain itu juga bertujuan untuk menentukan lokasi pelatihan, perserta yang terlibat, penentuan jadwal kegiatan.

b. Tahap Pretest

Kegiatan PKM diawali pre test akan pengetahuan tentang web. Pretes ini dilakukan dengan memberikan kousioiner pemahaman dasar tentang web kepada peserta,

c. Tahap sosialisasi

Pada tahap ini peserta diberikan materi dasar tentang teori web atau HTML dan web dinamis dan bagaiamna cara membuatnya. 


\section{d. Tahap Pelatihan}

Peserta dilatih membuat web sederhana atau dinamis seperti membuat blog dan wordpress serta mengelola web yang telah di buat.

e. Tahap pendampingan .

Pendampingan dilakukan 1 minggu dilakuakn pembuatan web sederhana yakni dengan memperbaruhi beranda web sederhana yang telah dibuat.

f. Tahap Post Test

Melakukan evaluasi pengetahuan materi yang telah didapatkan setelah dilakukan kegiatan PKM kepada peserta PKM dengan mengedarkan qusioner evaluasi kegiatan PKM.

\section{HASIL DAN PEMBAHASAN}

Kegiatan pengabdian dilakukan dengan metode presentasi pemateri dari dosen DIV Teknik infromatika Politeknik Harapan bersam dan teknik komputer, diskusi (Tanya Jawab), pelatihan dan pendampingan (praktek). Presentasi dilakukan untuk menyampaikan informasi umum tentang materi umum tentang web, pemahaman dalam pembuatan web sederhana. Sedangkan diskusi dan pendampingan dilakukan untuk materi tentang konsep web dan praktek pengelolaan web dinamis berupa pembuatan blog.

Hasil kegiatan pengabdian ini menunjukan bahwa peserta siswa-siswi kelas XII mendapatkan pengetahuan kaitannya dengan ilmu tentang web sederhana (dinamis) serta mendaptkan pengalaman dalam membuat blog, selain itu peserta juga dapat mengelola web sederhana yang telah dibuat. Pada kegiatan ini di idkuti oleh 35 siswa. Dalam kegiatan PKM ini peserta sangat antusias Hal ini dibuktikan dengan hasil blog yang telah di buat oleh peserta dan antusiasnya peserta pada saat mengikuti kegiatan pengabdian. Berikut foto-foto proses praktek seperti pada gambar 1 berikut ini:
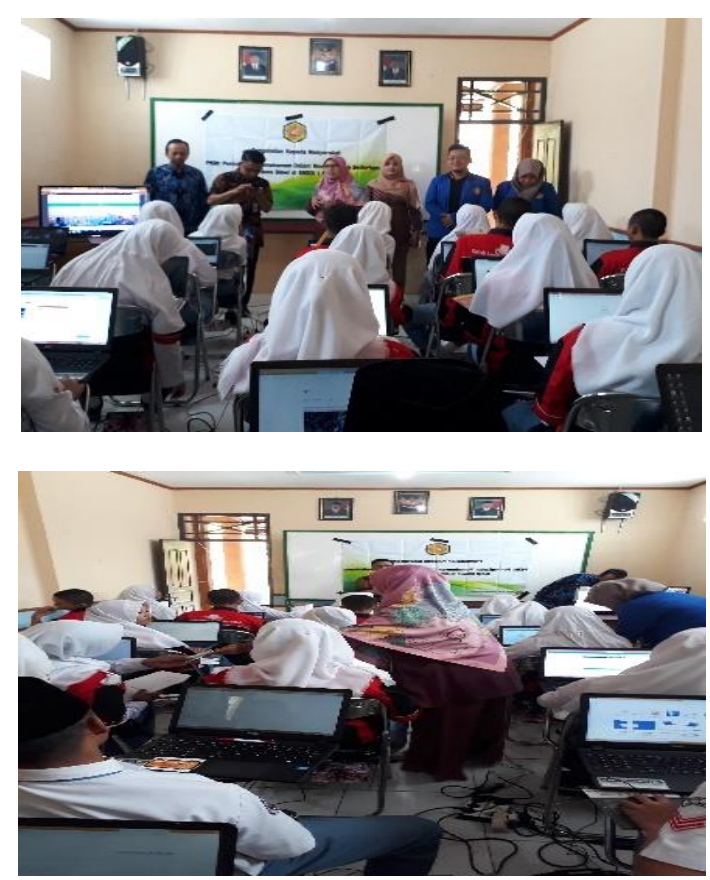

Gambar 1. Foto proses pembuatan blog.
Adapun sebagaian blog yang telah dibuat peserta yang digunakan dalam praktek pembuat blog antara lain:

- http/atmogayuh.blogspot.com

- http://saefulcbc.blogspot.com

- www. Rapidminerjat.blogspot.com

- muhammadyusro.blogspot.com

- http://sispalabalarata.blogspot.com/

Untuk mengukur sejauh mana tingkat keberhasilan kegiatan yang dilaksanakan, berdasarkan hasil qusioner yang telah disebarkan kepada para peserta kegiatan. Penilaian dilakukan dengan menggunakan nilai grid sebagai berikut: 1 = "Sangat tidak setuju", 2 = "Tidak Setuju", 3 = "cukup", 4 = "Setuju", dan 5 = "Sangat setuju".

Berdasarkan responden yang masuk, dari 32 responden peserta didapatkan hasil penilaian yang diperlihatkan pada Gambar 2.

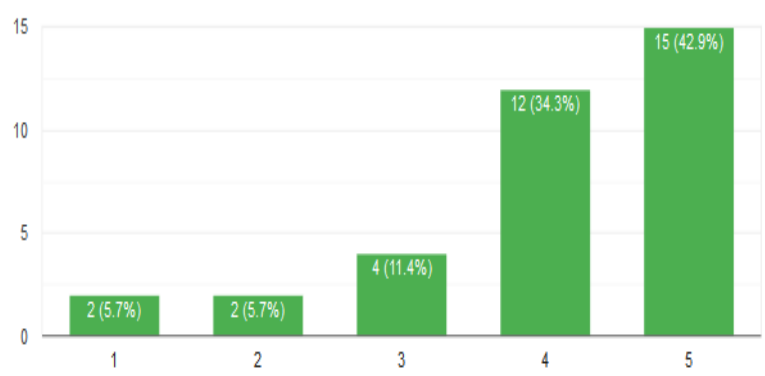

Gambar 2. Evaluasi kegiatan.

Berdasarkan hasil penilaian pada Gambar 2 terkait dengan materi yang disampaikan dan pelatihan serta pendampingan yang telah dilakukan bahwa kegiatan PKM dapat meningkatkan pengetahuan dan kemampuan peserta, terlihat bahwa dari saluruh responden $42 \%$ mengatakan "sangat setuju" dan 34\% mengatakan "setuju", sehingga apabila dijumlahkan responden yang melakuakn penilaian dengan nilai baik keatas adalah sebesar $76 \%$ bahwa materi dan pelatihan yang disampaikan menurus responden dapat meningktkan pengetahuan dan kemampuan peserta pelatihan.

\section{KESIMPULAN}

Pada kegiatan PKM yang telah dilakukan bahwa Peserta (siswa-siswi) Sekolah Menengah Kejuruan (SMK) Negeri I Bumijawa telah dapat mengenal pengetahuan bagaimana membuat, menggunakan web dinamis secara maksimal yang dibuktikan dengan peserta hasil web sederhana yang telah dibuat dan dikelola, hal ini dibuktikan dengan hasil evaluasi kegiatan yang telah di isi oleh peserta bahwa $76 \%$ peserta mengatakan memiliki respon yang sangat baik pada kegiatan PKM tersebut.

\section{UCAPAN TERIMA KASIH}

Tim PKM pada kesempatan ini kami menyampaikan ucapan terimakasih yang disampaikan kepada 
Politeknik Harapan Bersama yang telah memberikan dana PKM dan Kepada mitra PKM SMK Negeri 1 Bumijawa.

\section{DAFTAR PUSTAKA}

Edi Sarwo, Suharno, Widiastuti Endah. 2017. Pengembangan Standar Pelaksanaan Praktik Kerja Industri (Prakerin) Siswa SMK Program Keahlian Teknik Pemesinan di Wilayah Surakarta, JIPTEK, X(1), 22-30.

Kadir, Abdul. 2002. Dasar Pemrograman Web Dinamis Menggunakan PHP, Penerbit Andi.

Hasugian, Penda Sudarto. 2018. Perancangan Website Sebagai Media Promosi Dan Informasi. Journal Of Informatic Pelita Nusantara, 3(1), 82-86.

Wibisono \& Susanto, 2015. Perancangan Website Sebagai Media Informasi dan Promosi Batik Khas Kabupaten Kulonprogo, Evolusi, 3(2),6570

Trimarsiah, Yunita \& Arafat, Muhajir, 2017. Analisis Dan Perancangan Website Sebagai Sarana Informasi Pada Lembaga Bahasa Kewirausahaan Dan Komputer Akmi Baturaja, MATRIK 19(1), 1-10.

Profil Sekolah Sekolah Menengah Kejuruan Negeri 1 Bumijawa: http://www.smkn1bmj.sch.id/. Diakses pada tanggal 3 Juni 2018. Pukul 13.45 WIB. 